\title{
Analysis of Population Density and Family Wellbeing
}

\author{
Cindy Cahyaning Astuti \\ Fakultas Keguruan dan Ilmu Pendidikan \\ Universitas Muhammadiyah Sidoarjo \\ Sidoarjo, Indonesia \\ cindy.cahyaning@umsida.ac.id
}

\begin{abstract}
As a satellite city of Surabaya, Sidoarjo has a population of 1.8 million people spread across 18 districts. Sidoarjo has an area of $714.27 \mathrm{Km}^{2}$, so the population density reached 2521 people per $\mathrm{Km}^{2}$. But the greater the value of population density does not always have a negative impact. The purpose of this research is to know relationship between population density and the number of prosperous families in Sidoarjo 2015 using Pearson Correlation analysis . Based on this research there is a correlation of $85.9 \%$ between population density and number of prosperous families which means there is a positive relationship between population density and the number of prosperous families. Sidoarjo which grow into industrial area provides high job opportunity. In addition, house prices in Sidoarjo are relatively cheaper than Surabaya. These factors make many people from outside Sidoarjo choose to live in Sidoarjo. This makes the population density and the number of prosperous families being high.
\end{abstract} value

Keywords-population density; family wellbeing; correlation

\section{INTRODUCTION}

Population has two important things to see, quantity and quality of the population. Based on quality of population, every poeple wants a prosperous family. Population problems are closely related to family life and family wellbeing as a reflection of family quality [1]. Based on the quantity of population, if the population increases then the number of house needs will also increase. Research conducted in Depok, Sleman in 2012 proves that the rate of population growth is a reflection of the rate of home needs [2]. We know that the total area will not increase, and if it is accompanied by an increasing number of residents, the population density in a region will increase. The higher the population density will provide new problems in an area. But if population density increase can also have a positive impact.

There have been a lot of research that discuss the impact of increasing population density. Research conducted by Gobbi and Croix explains that increased population density will reduce fertility rates [3]. Research conducted by Rahman explains that increased population density has a negative impact on environmental quality in the long run [4]. Research conducted by Liu, Gao and $\mathrm{Lu}$ explains that urbanization makes urban population density increasing so as to increase greenhouse gas emissions [5]. Results of a paper discussion on demographics, house prices and mortgage design shows that if population density and income increases will increase house prices and of course the stock of houses will decrease [6]. Research conducted Karantonis in Sidney shows that population growth will increase the demand for housing. If there is no supply of new houses will increase the price of house rent and the selling price of the house [7]. Research conducted by Shabani, Akhari and Esfahani shows that the growth of population density have effect on economic growth [8].

Sidoarjo is a satellite city of Surabaya. Many workers in Surabaya choose to live in Sidoarjo. Most of them choose to live in Sidoarjo because the price of land and houses is cheaper when compared to the price of land and houses in Surabaya. Most of the workers chose Waru Sub-district, Sidoarjo as their home location. This makes the population density in Sidoarjo, especially Waru Sub-district to be very high. One of the effects is frequent jams, especially at 7 and 16 o'clock as can be seen in Figure 1.

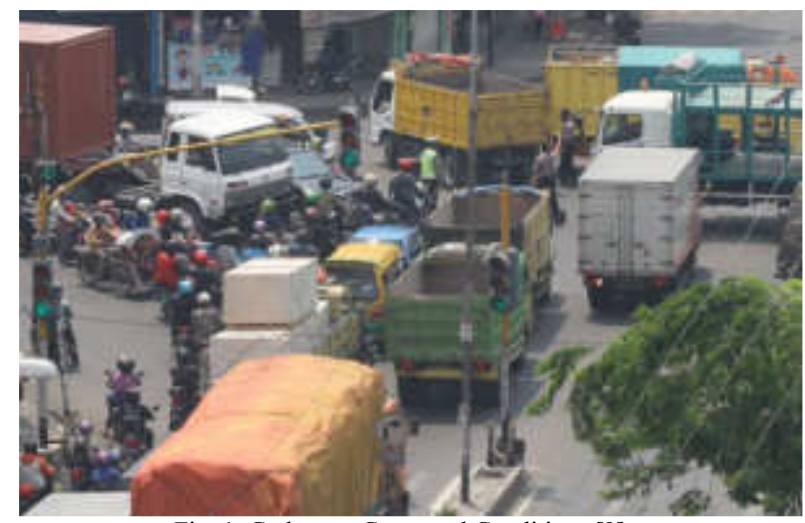

Fig. 1. Gedangan Crossroad Conditions [9]

If we want to look more deeply, there is still a lot of impact of high population density in Sidoarjo. Therefore, the purpose of this study is to dig deeper the impact of Population Density in Sidoarjo, including its relationship with family wellbeing. 


\section{RESEARCH MethodS}

In this study we used secondary data obtained from various sources. The study was conducted in Sidoarjo which has 18 sub-districts as can be seen in Table 1 .

TABLE 1. LIST SUB-DISTRICT OF SIDOARJO
\begin{tabular}{|c|c|c|c|}
\hline No & Sub-District & No & Sub-District \\
\hline 1 & Sidoarjo & 10 & Balongbendo \\
\hline 2 & Buduran & 11 & Wonoayu \\
\hline 3 & Candi & 12 & Tarik \\
\hline 4 & Porong & 13 & Prambon \\
\hline 5 & Krembung & 14 & Taman \\
\hline 6 & Tulangan & 15 & Waru \\
\hline 7 & Tanggulangin & 16 & Gedangan \\
\hline 8 & Jabon & 17 & Sedati \\
\hline 9 & Krian & 18 & Sukodono \\
\hline
\end{tabular}

Population density is calculated as population divided by total land area.

$$
\text { Population Density }=\frac{\text { Population }}{\text { Land Area }}
$$

To measure family wellbeing, we refer [10] where prosperous families are formed on the basis of legal marriage; Both material and spiritual needs are sufficient; devoted to God; have the same relationship, in harmony, balanced between family members with the community and the environment. Based on the level of wellbeing, the family is classified into 5 groups:

\section{Pre-Prosperous Family (PPF)}

Families who have not been able to meet basic needs at a minimum such as learning, religion, clothing, food, home and health.

\section{Prosperous Family Stage 1 (PFS1)}

Families can meet basic needs at a minimum (in accordance with basic needs in pre prosperous families) but have not been able to meet the psychological social needs of families such as education, family planning, family interaction and interaction with the environment.

3. Prosperous Family Stage 2 (PFS2)

Families who can meet basic and psychological needs but have not been able to meet development needs (saving money and obtaining information)

4. Prosperous Family Stage 3 (PFS3)

Families who can meet the needs of Stage 1 and 2 but have not been able to contribute maximally to the community and play an active role in society

5. Prosperous Family Stage $3+(\mathrm{PFS} 3+)$

Families who can meet the needs of phase 1 to 3 and can contribute maximally to the community and play an active role in the community

Meanwhile, to see the relationship of both, can be done with Pearson correlation analysis with the following formula:

$$
r=\frac{\sum_{i=1}^{n}\left(x_{i}-\bar{x}\right)\left(y_{i}-\bar{y}\right)}{\sqrt{\sum_{i=1}^{n}\left(x_{i}-\bar{x}\right)^{2}} \sqrt{\sum_{i=1}^{n}\left(y_{i}-\bar{y}\right)^{2}}}
$$

\section{RESULT AND DISCUSSION}

\section{A. Result}

1) Population Density Analysis

To find out the density of population in certain sub-district can be done calculation of population density by using equation 1 . The data needed for population density calculation is population and land area. The results of population density calculations can be seen in Table 2 .

\begin{tabular}{|l|r|r|r|}
\hline TuBL-District & $\begin{array}{c}\text { Population } \\
\text { (People) }\end{array}$ & $\begin{array}{c}\text { Land } \\
\text { Area } \\
\text { (Km2) }\end{array}$ & $\begin{array}{c}\text { Population } \\
\text { Density } \\
\text { (People/Km2) }\end{array}$ \\
\hline Sidoarjo & 171444 & 62.56 & 2740 \\
\hline Buduran & 78588 & 41.03 & 1915 \\
\hline Candi & 130793 & 40.67 & 3216 \\
\hline Porong & 56883 & 29.82 & 1908 \\
\hline Krembung & 57655 & 29.55 & 1951 \\
\hline Tulangan & 81050 & 31.21 & 2597 \\
\hline Tanggulangin & 73538 & 32.29 & 2277 \\
\hline Jabon & 47448 & 81 & 586 \\
\hline Krian & 108205 & 32.5 & 3329 \\
\hline Balongbendo & 64894 & 31.4 & 2067 \\
\hline Wonoayu & 66969 & 33.92 & 1974 \\
\hline Tarik & 61008 & 36.06 & 1692 \\
\hline Prambon & 69665 & 34.23 & 2035 \\
\hline Taman & 188323 & 31.54 & 5971 \\
\hline Waru & 224512 & 30.32 & 7405 \\
\hline Gedangan & 108740 & 24.06 & 4520 \\
\hline Sedati & 98815 & 79.43 & 1244 \\
\hline Sukodono & 112166 & 32.68 & 3432 \\
\hline
\end{tabular}

Based on these results can be seen that Waru Sub-District has the highest population density of 7405 people $/ \mathrm{Km}^{2}$. While the Sub-District has the smallest population density is Jabon District that is equal to $586 \mathrm{Km}^{2}$.

\section{2) Family Wellbeing Analysis}

Each family must have a family card (FC). FC is the identity of a family. In one $\mathrm{FC}$ there is at least 1 person. The number of FCs reflects the number of families. The number of families per sub-district in Sidoarjo District can be seen in Table 3.

TABLE 3. THE NUMBER OF FAMILIES IN SIDOARJO

\begin{tabular}{|l|c|c|c|}
\hline Sub-District & FC & Person & Person/FC \\
\hline Sidoarjo & 50111 & 171444 & 3 \\
\hline Buduran & 22310 & 78588 & 4 \\
\hline Candi & 36469 & 130793 & 4 \\
\hline Porong & 16805 & 56883 & 3 \\
\hline Krembung & 17572 & 57655 & 3 \\
\hline Tulangan & 23725 & 81050 & 3 \\
\hline Tanggulangin & 20712 & 73538 & 4 \\
\hline Jabon & 13894 & 47448 & 3 \\
\hline
\end{tabular}




\begin{tabular}{|l|c|c|c|}
\hline Sub-District & FC & Person & Person/FC \\
\hline Krian & 31377 & 108205 & 3 \\
\hline Balongbendo & 20133 & 64894 & 3 \\
\hline Wonoayu & 20645 & 66969 & 3 \\
\hline Tarik & 18299 & 61008 & 3 \\
\hline Prambon & 21528 & 69665 & 3 \\
\hline Taman & 49649 & 188323 & 4 \\
\hline Waru & 61029 & 224512 & 4 \\
\hline Gedangan & 31072 & 108740 & 3 \\
\hline Sedati & 24906 & 98815 & 4 \\
\hline Sukodono & 30782 & 112166 & 4 \\
\hline
\end{tabular}

Based on Table 3 it can be seen that the average of 1 family consists of 3 to 4 people in all sub-districts in Sidoarjo District.

The number of each group based on the level of family wellbeing we get from BPS which can be seen in Table 4.

TABLE 4. GROUPING BY FAMILY WELLBEING LEVEL

\begin{tabular}{|l|r|r|r|r|r|}
\hline Sub-District & PPF & PFS1 & PFS2 & PFS3 & PFS3+ \\
\hline Sidoarjo & 475 & 2361 & 5402 & 27744 & 14129 \\
\hline Buduran & 556 & 1202 & 1698 & 15214 & 3640 \\
\hline Candi & 1311 & 2144 & 6088 & 21869 & 5057 \\
\hline Porong & 1878 & 4064 & 3767 & 6292 & 804 \\
\hline Krembung & 765 & 2583 & 6011 & 6171 & 2042 \\
\hline Tulangan & 1192 & 2293 & 2590 & 14594 & 3056 \\
\hline Tanggulangin & 1627 & 2485 & 4374 & 8835 & 3391 \\
\hline Jabon & 2265 & 2516 & 4031 & 3570 & 1512 \\
\hline Krian & 1332 & 5105 & 8326 & 13731 & 2883 \\
\hline Balongbendo & 331 & 3087 & 4145 & 10537 & 2033 \\
\hline Wonoayu & 588 & 1749 & 2802 & 13332 & 2174 \\
\hline Tarik & 880 & 3376 & 8079 & 4537 & 1427 \\
\hline Prambon & 846 & 3281 & 8922 & 6217 & 1262 \\
\hline Taman & 1217 & 5667 & 12603 & 23701 & 6461 \\
\hline Waru & 326 & 6998 & 20155 & 22175 & 11375 \\
\hline Gedangan & 448 & 2049 & 4413 & 16555 & 7607 \\
\hline Sedati & 214 & 325 & 6462 & 12507 & 5398 \\
\hline Sukodono & 273 & 3912 & 5414 & 16997 & 4186 \\
\hline
\end{tabular}

The results of the percentage of each group can be seen in Table 5.

TABLE 5. PERCENTAGE OF GROUPS BASED ON FAMILY WELLBEING LEVEL

\begin{tabular}{|l|r|r|r|r|r|}
\hline Sub-District & \%PPF & \%PFS1 & \%PFS2 & \%PFS3 & \%PFS3+ \\
\hline Sidoarjo & $0.95 \%$ & $4.71 \%$ & $10.78 \%$ & $55.37 \%$ & $28.20 \%$ \\
\hline Buduran & $2.49 \%$ & $5.39 \%$ & $7.61 \%$ & $68.19 \%$ & $16.32 \%$ \\
\hline Candi & $3.59 \%$ & $5.88 \%$ & $16.69 \%$ & $59.97 \%$ & $13.87 \%$ \\
\hline Porong & $11.18 \%$ & $24.18 \%$ & $22.42 \%$ & $37.44 \%$ & $4.78 \%$ \\
\hline Krembung & $4.35 \%$ & $14.70 \%$ & $34.21 \%$ & $35.12 \%$ & $11.62 \%$ \\
\hline Tulangan & $5.02 \%$ & $9.66 \%$ & $10.92 \%$ & $61.51 \%$ & $12.88 \%$ \\
\hline Tanggulangin & $7.86 \%$ & $12.00 \%$ & $21.12 \%$ & $42.66 \%$ & $16.37 \%$ \\
\hline Jabon & $16.30 \%$ & $18.11 \%$ & $29.01 \%$ & $25.69 \%$ & $10.88 \%$ \\
\hline Krian & $4.25 \%$ & $16.27 \%$ & $26.54 \%$ & $43.76 \%$ & $9.19 \%$ \\
\hline Balongbendo & $1.64 \%$ & $15.33 \%$ & $20.59 \%$ & $52.34 \%$ & $10.10 \%$ \\
\hline Wonoayu & $2.85 \%$ & $8.47 \%$ & $13.57 \%$ & $64.58 \%$ & $10.53 \%$ \\
\hline Tarik & $4.81 \%$ & $18.45 \%$ & $44.15 \%$ & $24.79 \%$ & $7.80 \%$ \\
\hline Prambon & $4.12 \%$ & $15.98 \%$ & $43.46 \%$ & $30.29 \%$ & $6.15 \%$ \\
\hline Taman & $2.45 \%$ & $11.41 \%$ & $25.38 \%$ & $47.74 \%$ & $13.01 \%$ \\
\hline Waru & $0.53 \%$ & $11.47 \%$ & $33.03 \%$ & $36.34 \%$ & $18.64 \%$ \\
\hline Gedangan & $1.44 \%$ & $6.59 \%$ & $14.20 \%$ & $53.28 \%$ & $24.48 \%$ \\
\hline Sedati & $0.86 \%$ & $1.30 \%$ & $25.95 \%$ & $50.22 \%$ & $21.67 \%$ \\
\hline Sukodono & $0.89 \%$ & $12.71 \%$ & $17.59 \%$ & $55.22 \%$ & $13.60 \%$ \\
\hline
\end{tabular}

Based on Table 5 it can be seen that Waru Sub-District has the smallest percentage of PPF group that is $0.53 \%$, followed by Sedati and Sukodono Sub-District which have percentage of $0.86 \%$ and $0.89 \%$ respectively. Only after that Sidoarjo Sub-District which is the center of Sidoarjo District is $0.95 \%$.

\section{3) Correlation Analysis of Population Density and Family} Wellbeing

Prosperous families are the minimum family included in the PFS1 category. To calculate the number of prosperous families can be done by summing the PFS1, PFS2, PFS3 and PFS3 + groups. Population density and number of Prosperous Families can be seen in Table 6 .

TABLE 6. POPULATION DENSITY AND PROSPEROUS FAMILY IN SIDOARJO DISTRICT

\begin{tabular}{|c|c|c|}
\hline Sub-District & $\begin{array}{c}\text { Population Density } \\
\left(\text { Person } / \mathrm{Km}^{2}\right)\end{array}$ & $\begin{array}{c}\text { Prosperous Family } \\
\text { (Family) }\end{array}$ \\
\hline Sidoarjo & 2740 & 49636 \\
\hline Buduran & 1915 & 21754 \\
\hline Candi & 3216 & 35158 \\
\hline Porong & 1908 & 14927 \\
\hline Krembung & 1951 & 16807 \\
\hline Tulangan & 2597 & 22533 \\
\hline Tanggulangin & 2277 & 19085 \\
\hline Jabon & 586 & 11629 \\
\hline Krian & 3329 & 30045 \\
\hline Balongbendo & 2067 & 19802 \\
\hline Wonoayu & 1974 & 20057 \\
\hline Tarik & 1692 & 17419 \\
\hline Prambon & 2035 & 19682 \\
\hline Taman & 5971 & 48432 \\
\hline Waru & 7405 & 60703 \\
\hline Gedangan & 4520 & 30624 \\
\hline Sedati & 1244 & 24692 \\
\hline Sukodono & 3432 & 30509 \\
\hline
\end{tabular}

To know whether there is a relationship between the density of the population and prosperous families can be done with correlation analysis between the two as in equation (2). Correlation analysis result using correlation pearson method got result $85.9 \%$.

\section{B. Discussion}

Based on result, the very high population density in Sidoarjo District is located in sub-districts adjacent to Surabaya City such as Waru, Taman, Sukodono and Gedangan. Many workers in Surabaya City make these three sub-districts as their residence. In addition to the fact that the housing prices in Sidoarjo District are cheaper than in Surabaya City, the distance close to where they work to make the main reason.

Based on the level of family welfare, Waru Subdistrict which has the highest population density also has the highest number of prosperous families. The result of the correlation analysis between both of them is $85.9 \%$ which means that the population density and the number of prosperous families are closely related. The number of workers from Surabaya City who are minimum classified as Prosperous Family Stage 1 to stay in Sidoarjo make Prosperous Family number in Sidoarjo District especially Waru Sub-District, Taman, Sukodono and Gedangan high. Sidoarjo Sub-District is a place for residents belonging to Prosperous Family Stage 3 and Prosperous 
Family Stage 3+ because it is the center of Sidoarjo District. Krian and Candi Sub-District is an industrial area that absorbs a lot of workers who enter the minimum class Prosperous Family Stage 1, because that's Prosperous Family number is high enough.

\section{CONCLUSION}

Based on our research there is a correlation of $85.9 \%$ between population density and number of prosperous families which means there is a positive relationship between population density and the number of prosperous families. Increased of population density does not always have a negative impact on the number of prosperous families. With the availability of new jobs and property prices are still cheaper than Surabaya, making the population density of Sidoarjo increasing, and also increase the number of prosperous families.Sidoarjo which grow into industrial area provides high job opportunity. In addition, house prices in Sidoarjo are relatively cheaper than Surabaya. These factor make many people from outside Sidoarjo choose to live in Sidoarjo. This makes the population density and the number of prosperous families being high.

\section{ACKNOWLEDGMENT}

Thanks to Universitas Muhammadiyah Sidoarjo for support this article. Hopefully this research is useful especially for increasing the number of prosperous family in Sidoarjo.

\section{REFERENCES}

[1] E. Sunarti. Kependudukan dan Keluarga Sejahtera, Jakarta: Direktorat Analisis Dampak Kependudukan BKKBN, 2011,

[2] B. Setyorini, Analysis of Population Density and Setllement Projection in Depok Sub District, Sleman 2010-2015, Surakarta: Universitas Muhammadiyah Surakarta, 2012.

[3] P. E. Gobbi and D. d. 1. Croix, "Population density, fertility, and demographic convergence in developing countries," Journal of Development Economics, vol. 127, pp. 13-24, 2017.

[4] M. M. Rahman, "Do population density, economic growth, energy use and exports adversely affect environmental quality in Asian populous countries?," Renewable and Sustainable Energy Reviews, vol. 77, pp. 506-514, 2017.

[5] Y. Liu, C. Gao and Y. Lu, "The impact of urbanization on GHG emissions in China: The role of population density," Journal of Cleaner Production, vol. 157, pp. 299-309, 2017.

[6] D. Miles, External MPC Unit Discussion Paper No. 35 Demographics, house prices and mortgage design, London: Bank of England, 2012.

[7] A. Karantonis, "Population Growth and Housing Affordability in the Modern City - Sydney a Case Study," 14th Pacific Rim Real Estate Society Conference, 2008-01, pp. 1-16. 2008.

[8] Z. D. Shabani, N. Akbari, R. D. Esfahani, "Effect of Population Density, Division and Distance on Regional Economic Growth," Iranian Economic Review, vol. 16, pp. 101-121, 2011.

[9] S. Deas, Photographer, Gedangan Crossroad Conditions That Like Tangled Threads. [Photo]. Jawa Pos, 2014.

[10] H. Permatasari, "Konsep Keluarga Sejahtera," 2009. [Online]. Available:

https://statistikaterapan.files.wordpress.com/2011/02/pengertiankeluarga-sejahtera.pdf\#page=1\&zoom=auto,-211,548. [Accessed 2017]. 